\section{Preclinical studies with JAA-F11 anti-Thomsen-Friedenreich monoclonal antibody for human breast cancer}

\author{
Kimiko Ferguson', Arti Yadav', Susan Morey', Julia Abdullah', \\ Gabriel Hrysenko', Jing Ying Eng', Munawwar Sajjad ${ }^{2}$, Stephen Koury' \\ \& Kate Rittenhouse-Olson ${ }^{* 1,3,4,5}$
}

\begin{abstract}
Aim: The Thomsen-Friedenreich antigen (TF-Ag) is a disaccharide hidden on normal cells, but selectively exposed on the surface of breast, colon, prostate and bladder cancer cells. JAA-F11, a highly specific monoclonal antibody to TF-Ag, reduces metastasis and prolongs survival in a mouse model. In addition, ${ }^{124} \mathrm{I}-\mathrm{JAA}$-F11 localizes 4T1 tumors in mice. These studies continue translation of JAA-F11 to human breast cancer. Materials \& methods \& results: Of the 41 human breast cancer cell lines tested, $78 \%$ were positive for reactivity with JAA-F11 by whole-cell enzyme immunoassay and positivity occurred unrelated to estrogen, progesterone or HER2 receptor status. JAA-F11 inhibited the growth rate of the human cancer cell lines tested. At $1 \mathrm{~h}$, approximately $80 \%$ of JAA-F11 internalized in the three cell lines tested. ${ }^{124} \mathrm{I}-\mathrm{JAA}-\mathrm{F} 11$ specifically imaged human triple-negative tumors in mice by microPET. Conclusion: The results highlight the potential that humanized JAA-F11 may have for immunotherapy and drug conjugate therapy in breast cancer patients.
\end{abstract}

\section{Background}

Breast cancer is one of the most prevalent cancers in women worldwide $[1,2]$ and is the most common cause of cancer deaths in women [2]. The deaths related to breast cancer are not due to the primary tumors, but are due to the metastases to the lungs, brain and bone $[3,4]$. Therefore, treatment and management to block metastases is an important target for therapy that would improve survival in breast cancer patients.

Irregularities in cell adhesion play an important role in cancer progression and metastasis [5]. The Thomsen-Friedenreich antigen (TF-Ag) is the disaccharide, galactose- $\beta 1-3 \mathrm{~N}$-acetyl galactosamine (Gal $\beta 1-3 \mathrm{GalNAc}) \alpha$-O-linked to serine or threonine residues in glycoproteins [6]. It is a tumor-associated antigen, which is covered by other carbohydrate moieties and thus hidden in normal cells, but exposed in cancers such as breast, lung, prostate and bladder [6-9]. TF-Ag plays a role in cancer cell adhesion and metastasis as a result of interacting with lectins at metastatic sites $[10,11]$. One particular lectin that interacts with the TF-Ag to establish metastasis is galectin-3. This interaction may provide an explanation for the direct relationship between TF-Ag expression, galectin-3 expression and cancer metastasis and aggression, with patients having elevated galectin-3 levels and tumor cells bearing elevated TF-Ag levels having the most aggressive, metastatic cancers $[11,12]$. Previous studies proposed that TF-Ag and galectin-3 interaction with galectin-3 mobilization to the endothelial cell surface is involved in the first step of a two-step tumor cell-endothelial cell interaction for tumor adhesion and metastasis [10]. This step is followed by an integrin-mediated

'Department of Biotechnical \& Clinical Laboratory Sciences, University of Buffalo, Buffalo, NY 14214, USA

2Department of Nuclear Medicine, University of Buffalo, Buffalo, NY 14214, USA

${ }^{3}$ Department of Social \& Preventative Medicine, University of Buffalo, Buffalo, NY 14214, USA

${ }^{4}$ Department of Microbiology \& Immunology, University of Buffalo, Buffalo, NY 14214, USA

${ }^{5}$ Robin Therapeutics, 97 Troy View Lane, Buffalo, NY 14221, USA

*Author for correspondence: Tel.: +1 716829 5195; Fax: +1 716829 3601; krolson@buffalo.edu

\section{KEYWORDS}

- enzyme immunoassay

- human breast cancer cell lines $\bullet$ JAA-F11 monoclonal antibody $\bullet$ monoclonal antibody • ThomsenFriedenreich antigen 
locking in order to establish and maintain the metastasis [10]. This elucidates the critical role that the TF-Ag has in cancer metastasis. If this antigen can be blocked from interacting with the galectin-3, reduction of metastasis should follow, which would lengthen the life of the patient. In addition, antibody to TF-Ag will allow immunotherapy or antibody-drug targeting of up to $80 \%$ of all associated carcinomas.

The mouse monoclonal antibody (mAb), JAA-F11 was shown to be highly specific for the tumor-associated TF-Ag, in that it binds Gal $\beta 1-3$ GalNAc $\alpha$-linked, but not the Gal $\beta 1$ 3GalNAc $\beta$-linked structure [6,13-14]. The chemical specificity was shown in the TF-Ag-specific binding of JAA-F11 on a 221 member glycan array $[6,13,14]$. This specificity is critical as it indicates that JAA-F11 should bind only to cancer cells and not normal cells, such as kidney and NK cells, which express the Gal $\beta 1-3$ GalNAc $\beta$-linked glycolipids. An important example of a less specific antibody is Tru-Scint $\mathrm{mAb}$ $170 \mathrm{H} .82$, an antibody to the $\alpha$ - and $\beta$-linked TF-Ag [15]. Tru-Scint mAb 170H.82 underwent partially successful clinical trials, but was withdrawn after Phase III clinical trials, presumably because although tumor imaging was seen, the antibody also bound normal kidney cells [15].

Studies utilizing JAA-F11 have been successful in confirming the specificity of JAA-F11 to TF-Ag, as well as its antimetastatic effect $[6,10,13,14]$. Specificity was confirmed in vivo in mice intravenously injected with ${ }^{124} \mathrm{I}$ JAA-F11, located specifically at the site of the TF-Agpositive $4 \mathrm{~T} 1$ mouse breast tumor, where it remained for greater than 20 days [6]. This shows that ${ }^{124} \mathrm{I}$ JAA-F11 is specific to the $\alpha$-linked TF-Ag in vivo, which is not exposed in normal tissue and can be used in the detection of metastatic tumors bearing the TF-Ag. The antimetastatic effect was shown in in vivo, ex vivo and in vitro models of metastasis. In vivo, 4T1 tumor-bearing mice treated with JAA-F11 had fewer lung metastases and had increased survival time as opposed to mice not treated with the JAA-F11 $[6,16]$. In another in vivo model, colon cancer cells are inhibited from implantation in rat lungs after intravenous injection [17]. Ex vivo, JAA-F11 inhibits human prostate and breast cancer cells from sticking and rolling on porcine dura mater [16]. In vitro, JAA-F11 inhibited sticking of breast and prostate cancer cells to human umbilical vein endothelial cells and human bone marrow-derived endothelial cells [16]. This metastasis-blocking property and specificity in mice makes JAA-F11, once humanized, highly promising for future human studies in cancer patients.

Since studies with JAA-F11 have been limited to only a few mouse and human cancer cell lines, the goal of this study was to assess the binding of JAA-F11 on 41 human breast tumors cell lines as an indicator for future human cancer patient applicability. In total, 40 different tumor cells used in this study are from The Breast Cancer Panel of human breast cancer cell lines from the American Type Culture Collection (ATCC). These cell lines have been characterized for their expression of the estrogen receptor, the progesterone receptor and the HER2 receptor. One additional cell line (MDA-MD-435) was utilized. In addition, imaging was performed using three triple-negative, TF-Ag-positive tumors to determine if the in vitro expression correlated with in vivo binding of TF-Ag-positive tumors. There is no specific targeted treatment for triple-negative breast cancer [18] and these studies using JAA-F11 are a useful step forward in determining if it can be effective against such cancers. Cell proliferation and cell internalization experiments complete the preclinical testing of JAA-F11 described in this study.

\section{Materials \& methods \\ - JAA-F11 mAb}

The JAA-F11 hybridoma was developed in our laboratory and the description of its production and early characterization can be seen in [14]. It was produced using spleen cells of a mouse immunized three times with Gal $\beta 1-3 \mathrm{GalNAc-}$ $\mathrm{OCH}_{2} \mathrm{CH}_{2}-\mathrm{S}-\mathrm{CH}_{2} \mathrm{CH}_{2} \mathrm{NHCOCH}_{2} \mathrm{CH}_{2} \mathrm{BSA}$ in complete Freund's adjuvant. Cells producing this antibody were cultured in 5\% ultra-low immunoglobulin fetal calf serum (GIBCO, Life Technologies, NY, USA) in Dulbecco's modified Eagle medium with added L-glutamine, sodium pyruvate and nonessential amino acids (Mediatech, VA, USA). JAA-F11 was purified using triple ammonium sulfate precipitation to $33.3 \%$ saturation followed by Cibacron Blue 3GA affinity chromatography (Sigma-Aldrich, MO, USA) [19].

\section{- Human breast cancer cell lines}

The Breast Cancer Panel of 45 breast cancer cell lines characterized for expression of estrogen, progesterone and HER2 receptor expression was purchased from the ATCC (ATCC Breast 
Cancer Cell Panel of 45 cell lines [ATCC ${ }^{\circledast}$ 30-4500K ${ }^{\mathrm{TM}}$; Manassas, VA, USA]) [20]. The cell lines were cultured in vitro under standard cell culture conditions $\left(37^{\circ} \mathrm{C}, 100 \%\right.$ relative humidity, $5 \% \mathrm{CO}_{2}$ ) in the respective medium and supplements suggested by the ATCC. Five cell lines from the ATCC panel were not analyzed because of their poor growth rate. One additional cell line, MDA-MD-435 was analyzed.

\section{- Whole-cell enzyme immunoassay to assess JAA-F11 binding to human cancer cell lines}

Cell preparation

Whole-cell enzyme immunoassay (EIA) was performed to test the expression of TF-Ag on the surface of the ATCC human breast cancer cell lines. The mouse breast cancer cell line, 4T1, an animal model for metastatic human breast cancer $[6,13-14,16]$ served as the TF-Agpositive control. The myeloma, X63Ag8.653, the fusion partner for producing the JAA-F11 hybridoma [14], served as the TF-Ag-negative control. The breast cancer cell lines, myeloma and $4 \mathrm{~T} 1$ cell lines were harvested using nonenzymatic 1X Cell Dissociation Solution (Sigma Aldrich, MO, USA). A total of $200 \mu \mathrm{l}$ of the cell suspension $\left(2 \times 10^{5}\right.$ cells $)$ were placed in $5 \mathrm{ml}$ polystyrene tubes. A further $200 \mu \mathrm{l}$ of $4 \%$ formaldehyde solution was added to each tube and incubated for $20 \mathrm{~min}$ at room temperature. After this period, the cells were centrifuged for $10 \mathrm{~min}$ at $1500 \times g$ and the supernatant was carefully decanted. A total of $200 \mu \mathrm{l}$ of phosphatebuffered solution (PBS), 0.1\% Tween 20, 1\% bovine serum albumin (BSA; weight/volume) was added to each tube and stored at $4^{\circ} \mathrm{C}$ overnight or up to 2 weeks.

\section{EIA on whole cells}

On the day of the experiment, $200 \mu \mathrm{l}$ of $100 \mu \mathrm{g} / \mathrm{ml}$ of the JAA-F11 mAb, in triplicate, was added to the tubes and incubated at $37^{\circ} \mathrm{C}$ for $2 \mathrm{~h}$. One set of triplicate tubes was treated at this step with $200 \mu \mathrm{l}$ of $1 \times$ PBS $-0.1 \%$ Tween $20-1 \%$ BSA for the negative control for each cell line. The tubes were washed three times with $3 \mathrm{ml}$ of PBS Tween, centrifuged for $10 \mathrm{~min}$ at $1500 \times \mathrm{g}$, and carefully decanted between washes. A total of $200 \mu \mathrm{l}$ of antimouse IgG ( $\gamma$-chainspecific) horseradish peroxidase secondary antibody (1:500, $0.7 \mathrm{mg} / \mathrm{ml}$; Sigma Aldrich) in PBS-Tween-1\% BSA was added to each tube, incubated for $1 \mathrm{~h}$ at room temperature, and then washed three times at $1500 \times \mathrm{g}$. A total of $200 \mu \mathrm{l}$ of $O$-phenylenediaminedihydrochloride substrate (Sigma Aldrich) solution was added to each tube and incubated for $1 \mathrm{~h}$ at room temperature. The reaction was stopped using $1 \mathrm{~N}$ $\mathrm{H}_{2} \mathrm{SO}_{4}$ and the tubes were centrifuged for 10 min at $1500 \times g$. In total, $200 \mu \mathrm{l}$ of supernatant from these tubes was added to respective wells in a microtiter plate and read at $490 \mathrm{~nm}$ using a microplate reader (Microplate Autoreader, Model EL311, Bio-Tek Instruments, Inc., VT, USA) with unreacted $O$-phenylenediamine dihydrochloride substrate as blank. Each experiment was repeated three times.

\section{- MTT assay to assess the effect of JAA-F11 on human cancer cell proliferation}

A growth curve for two TF-Ag-positive cell lines was performed before starting the experiment to ensure the number of cells seeded in each well represented the log phase of growth. T47D (1.25 × $10^{5}$ cells/well) and HCC1937 $\left(1.25 \times 10^{5}\right.$ cells/well $)$ cell lines were plated in 12 replicates in 96-well plates in the presence of varying amounts of either JAA-F11 or peanut agglutinin (PNA; a TF-Ag-binding lectin) for a final concentration of $(4,2$ and $1 \mu \mathrm{g} / \mathrm{ml})$. The cell lines were also grown in culture medium without any antibody or lectin and 12 replicates of culture medium alone were prepared to serve as the negative controls and the blank, respectively. After $68 \mathrm{~h}$ of cell growth, $10 \mu \mathrm{l}$ sterile MTT was added and incubated for $4 \mathrm{~h}$. A total of $120 \mu \mathrm{l}$ of $5 \%$ formic acid in isopropanol was added with mixing to solubilize the formazan product. The plate was read on a microplate reader (Microplate Autoreader, Model EL311, Bio-Tek Instruments, Inc.) at $570 \mathrm{~nm}$.

\section{- JAA-F11 internalization analysis}

Three cell lines were tested for internalization: the mouse 4T1 breast cancer cell line, the human BT549 (triple negative) and CAMA-1 (estrogen receptor $\left.[\mathrm{ER}]^{+}\right)$. The cell lines were grown to confluence in all six wells of two six-well plates. In each plate, the media was decanted, and in three wells in each plate, $1 \mathrm{ml}$ of JAA-F11 was added at $0.2 \mathrm{mg} / \mathrm{ml}$; in the remaining three wells, $1 \mathrm{ml}$ of media alone was added. One of the six-well plates was incubated at $37^{\circ} \mathrm{C}$ to allow internalization and the other plate was incubated at $4^{\circ} \mathrm{C}$. After $1 \mathrm{~h}$, the $1 \mathrm{ml}$ was removed and the wells were gently washed four times with RPMI media 
RESEARCH ARTICLE Ferguson, Yadav, Morey et al.
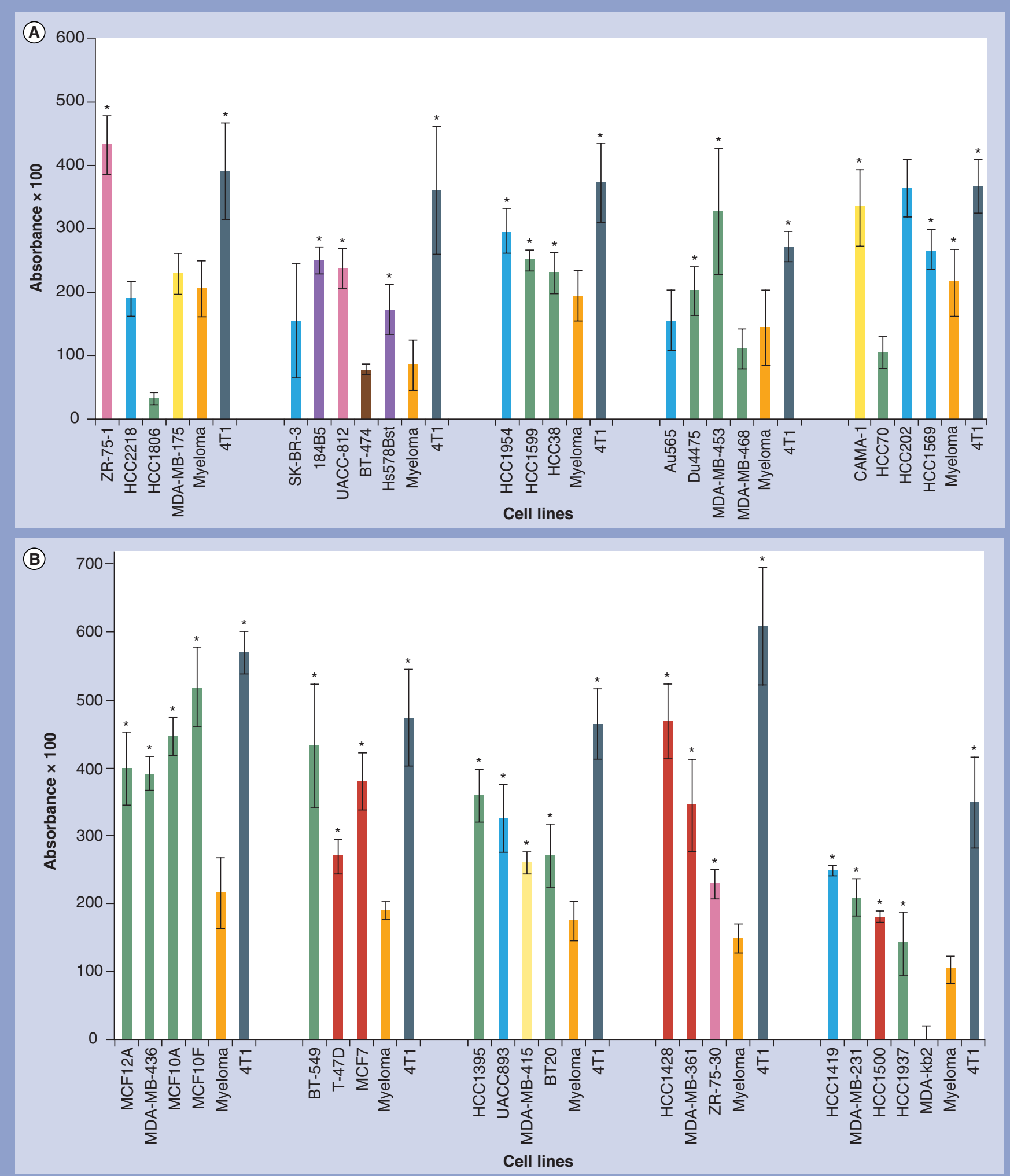

\begin{tabular}{|lll|}
\hline $\mathrm{ER}^{+} / \mathrm{PR} / \mathrm{HER} \mathrm{R}^{+}$ & $\mathrm{HER} 2^{+}$ & Triple negative \\
$\mathrm{ER} / \mathrm{PR}$ & Negative control & Positive control \\
Immortalized normal & $\mathrm{ER}^{+} / \mathrm{PR}^{+} / \mathrm{HER}^{+}$ & $\mathrm{ER}^{+} / \mathrm{PR}^{+}$ \\
\hline
\end{tabular}


Figure 1. Results of enzyme immunoassay conducted with JAA-F11 (100, 50, 25 and $12.5 \mu \mathrm{g} / \mathrm{ml})$ and breast cancer cell lines HCC1419, MDA-MB-231, HCC1500, HCC-1937 and MDA-kb2 (see facing page). (A) The cell lines are shown in the order named. ER ${ }^{+} / \mathrm{PR}^{+}$ lines are shown in red, $\mathrm{ER}^{+} / \mathrm{PR}^{-}$lines are shown in yellow, triple-negative lines are shown in green, HER2 $2^{+}$lines in blue, immortalized normal lines in purple and the transformed MDA-kb2 line is at baseline. Cell lines that are $\mathrm{ER}^{+} / \mathrm{PR}^{+}$and $\mathrm{HER}^{+}$are shown in brown, cell lines that are $\mathrm{ER}^{+} / \mathrm{PR}^{-}$and $\mathrm{HER2} 2^{+}$are shown in pink. Myeloma cells, the negative control is in orange and 4T1 the positive control is shown in gray. The asterisks indicate that the value for the cell line is statistically greater than the myeloma control ( $p=0.05)$. (B) Shows the remaining cell lines in the same manner.

ER: Estrogen receptor; PR: Progesterone receptor.

(Life Technologies). After the fourth wash, the media was removed and $1 \mathrm{ml}$ of $2 \%$ paraformaldehyde was added to each well and the plates were incubated at room temperature for $20 \mathrm{~min}$ to fix the cells without permeabilizing the membrane. The paraformaldehyde was freshly made from powder, since paraformaldehyde that is commercially available contains methanol and causes membrane permeabilization. The plates were washed four times with media and $1 \mathrm{ml}$ of anti-mouse IgG ( $\gamma$-chain-specific) alkaline phosphatase secondary antibody (1:5000, Sigma Aldrich) was added and incubated at $37^{\circ} \mathrm{C}$ for 1 h. The plates were washed four times with media and $1 \mathrm{ml}$ of $p$-nitrophenyl phosphate at $1 \mathrm{mg} / \mathrm{ml}$ was added and incubated for $1 \mathrm{~h}$ at $37^{\circ} \mathrm{C}$. At $1 \mathrm{~h}, 200 \mu \mathrm{l}$ from each well was pipetted into a 96-well plate. Absorbancies were read at 405 nm. Unreacted substrate served as the blank. The triplicate wells were averaged, the average optical density of the media alone blank was subtracted from the wells containing antibody. The percentage internalization was given as follows:

$\%$ internalization $=1-\frac{\left(a b s 37^{\circ} \mathrm{C} \text { sample }-a b s 37^{\circ} \mathrm{C} \text { blank }\right)}{\left(a b s 4^{\circ} \mathrm{C} \text { sample }-a b s 4^{\circ} \mathrm{C} \text { blank }\right)} \times 100$

\section{- Radiolabeling of JAA-F11 via the Bolton-Hunter method}

The Bolton-Hunter method was performed for radiolabeling JAA-F11. ${ }^{124} \mathrm{I}$ was distilled and dried in a small reaction vial $(0.3 \mathrm{ml}$, Wheaton, NJ, USA). A solution of $\mathrm{NaI}$ carrier was added to ${ }^{124} \mathrm{I}$ after measuring its starting activity. Hydrochloric acid and sodium phosphate buffer was then added while mixing. The mixture was incubated at room temperature for $10 \mathrm{~min}$. $\operatorname{SHPP}(N$-succinimidyl-3-[4-hyd roxyphenyl propionate]) in 1,4-dioxane, and chloramine$\mathrm{T}$, were added while mixing, and the reaction was terminated $(\sim 10-15 \mathrm{~s})$ with a sodium PBS. The activity was measured in a $\gamma$-counter. The product of the reaction was extracted with benzene/dimethylfluoride. It was then dried on a column of $\mathrm{Na}_{2} \mathrm{SO}_{4}$ in another reaction vial. The activity in the extraction vial after drying was measured. JAA-F11 $(7.5 \mathrm{mg} / \mathrm{ml}, 10 \mu \mathrm{g} /$ mouse, in borate buffer saline) was mixed with sodium borate buffer $(\mathrm{pH} 8.5,100 \mathrm{mM})$ in 2:1 ratio and incubated with ${ }^{124} \mathrm{I}-\mathrm{SHPP}$ at $0^{\circ} \mathrm{C}$ for $1 \mathrm{~h}$. The activity was measured after $1 \mathrm{~h}$. The labeled antibody was isolated using a Sephadex G-25 column. A total of 20 fractions of 500 $\mu \mathrm{l}$ each were collected with PBS as the elution buffer. The ${ }^{124} \mathrm{I}-\mathrm{JAA}-\mathrm{F} 11$ was analyzed for its TF-Ag-binding activity by radioimmunoassay to ensure that no loss of activity occurred due to labeling.

\section{- Animals \& tumor models}

All the animals were treated in accordance with the Institutional Animal Care and Use Committees regulations. Human tumors took 5-8 weeks of growth in female severe combined immunodeficiency (SCID) and nude mice. The breast cancer cells (MDA-MB-435 and MDA-MB-231 [ATCC]) were implanted by injecting 1-3.5 × $10^{6}$ cells in $0.1 \mathrm{ml}$ Dulbecco's PBS (DPBS) subcutaneously under one of the right nipples of a SCID mouse. SCID mice were a gift from Richard Bankert at the University at Buffalo (NY, USA). A TF-Agpositive (DU 4475 ATCC HTB-123 [ATCC]) cell line, and one TF-Ag-negative (MDA MB 468 ATCC HTB-132) breast cancer cell line were injected into two 6-8-week-old female nude mice. The TF-Ag-positive breast cancer cell lines were implanted by injecting $1 \times 10^{7}$ cells in $0.1 \mathrm{ml}$ DPBS subcutaneously under one of the right nipples of each nude mouse (strain J:NU Foxn1nu homozygous; Jackson Labs, ME, USA), while the TF-Ag-negative breast tumor cell line (MDA-MB-468) was injected into the left flank of each mouse. The mice were monitored for tumor growth.

The MDA-MB-435, MDA-MB-231 and the DU 4475 cell lines have all been characterized as triple-negative breast cancer cell lines. The etiology of the MDA-MB-435 as a triple-negative breast cancer with a basal-like 
morphology has become controversial [21-23], but the MDA-MB-231 has been further characterized as triple negative with a mesenchymal origin [20] and the DU 4475 has been further characterized as triple negative with a basal-like morphology [20].

\section{- Experimental model}

Mice received autoclaved $0.2 \mathrm{~g} / \mathrm{l} \mathrm{KI}$ water (deionized $\mathrm{H}_{2} \mathrm{O}$ ) to block thyroid uptake $24-48 \mathrm{~h}$ prior to receiving the ${ }^{124}$ I-JAA-F11. Mice received a tail vein infusion of $10 \mu \mathrm{g}$ JAA-F11 labeled with $10-120 \mu \mathrm{Ci}^{124} \mathrm{I}$ in $0.1 \mathrm{ml}$ PBS. In the first analyses shown, MDA-MB-435 tumor SCID mice were given intraperitoneal injections with sterile-filtered mouse IgG (lyophilized powder, $46 \mathrm{mg}$ per mouse in $0.1 \mathrm{ml}$ DPBS, Equitech-Bio Inc., TX, USA) $24 \mathrm{~h}$ prior to injecting ${ }^{124} \mathrm{I}-\mathrm{JAA}-\mathrm{F} 11$. In the second and third analyses shown, MDA-MB-231 tumor-bearing SCID mice and the DU 4475 ATCC HTB-123 and TF-Ag-negative (MDA MB 468 ATCC HTB-132)-bearing nude mice were injected with radiolabeled antibody without pretreatment with cold antibody. MicroPET imaging was performed on all groups.

\section{- PET imaging of human triple-negative} breast cancer cell lines in SCID or nude mice SCID bearing MDA-MB-435, MDA-MB-231 or nude mice bearing DU 4475 were imaged by microPET at $48,144,240,360$ and $480 \mathrm{~h}$ after injection of the ${ }^{124}$ I-JAA-F11 and were sacrificed on the last day of the study. The mice were anesthetized in a sterile chamber connected with $1-2 \%$ isofluorane. After becoming unconscious, mice were placed on the sterile bed of the microPET camera (Focus $120^{\circledR}$; Concorde Microsystems, TN, USA). Mice were provided with a flow of $\mathrm{O}_{2}$ /isofluorane to maintain anesthesia. The emission scan window was set between 350 and $750 \mathrm{keV}$. The animal was scanned for 30 min for ${ }^{124} \mathrm{I}$ in the prone position in the gantry of the microPET scanner. The transmission scan of some mice was also performed using a ${ }^{57}$ Co point source for $9 \mathrm{~min}$. The transmission scan window was set between 120 and $125 \mathrm{keV}$. Data analysis and image reconstruction was performed with filtered back projection $2 \mathrm{D}$ using the software microPET manager 2.2.4.0 (Siemens Preclinical Solutions, Erlangen, Germany).

\section{- Statistical analysis}

In the EIA, a two-tailed unpaired t-test was utilized to compare each human breast cancer cell line with the myeloma cell line negative control. Significance was set at $\mathrm{p} \leq 0.05$. In the MTT assays, a two-tailed unpaired t-test was utilized to compare each treatment concentration with the control of media alone. The Pearson correlation coefficient analysis was used to correlate dose with concentration of each treatment in the MTT assay.

\section{Results}

\section{- Whole-cell EIA to assess JAA-F11 binding} to human cancer cell lines

The whole-cell EIA with JAA-F11 was used to test for the presence of JAA-F11 binding TF-Ag on the surface of the breast cancer cell lines from the ATCC panel. A cell line was considered positive if the relative binding due to JAA-F11 (at $100 \mu \mathrm{g} / \mathrm{ml}$ ) was significantly higher ( $\mathrm{p} \leq$ 0.05) than that of the TF-Ag negative control myeloma. The TF-Ag-positive 4T1 cell line $[6,13-14,16]$ served as the TF-Ag positive control. Three to five cell lines were assayed at a time, in triplicate, with the control cell lines. Each such assay was repeated on three different days.

Of the 41 cell lines tested, 32 were positive for the TF-Ag (80\%). Of the tested cell lines, one, MDA-kb2, was a manipulated cell MDA-MD-453 with a luciferase reporter [24], one was MDA-MB-435, whose origins are now controversial [21-23] and two were immortalized nonmalignant cell lines (184B5 and Hs578Bst); removing these cell lines, of the 37 remaining cell lines, 29 are positive for TF-Ag (78\%). In Figure $1, \mathrm{ER}^{+} /$progesterone receptor $(\mathrm{PR})^{+}$lines are shown in red, $\mathrm{ER}^{+} / \mathrm{PR}^{-}$lines are shown in yellow, triple-negative lines are shown in green, HER 2+ lines in blue, transformed but nonmalignant cell lines in purple, and the androgenresponsive transformed MDA-kb2 line is at baseline. Cell lines that are $\mathrm{ER}^{+} / \mathrm{PR}^{+}$and HER2 ${ }^{+}$ are brown, and cell lines that are $\mathrm{ER}^{+}, \mathrm{PR}^{-}$and $\mathrm{HER}^{+}{ }^{+}$are pink. The myeloma cell line, the negative control, is in orange and $4 \mathrm{~T} 1$, the positive control, is shown in gray. Each cell line was performed in triplicate, and the entire assays were also repeated three times. These results are listed in Table 1 [21-29] and the percentage JAA-F11-reactive TF-Ag-positive cell lines for each breast cancer subtype are in shown in Figure 2. Of all the triple negatives tested, $80 \%$ (12/15) were JAA-F11-reactive TF-Ag-positive; of the $\mathrm{ER}^{+}$and $\mathrm{PR}^{+}$cell lines tested, $86 \%(6 / 7)$ were JAA-F11-reactive TF-Ag positive; of the $\mathrm{ER}^{+}$and $\mathrm{PR}^{-}$tested, 83\% (5/6) were positive. 


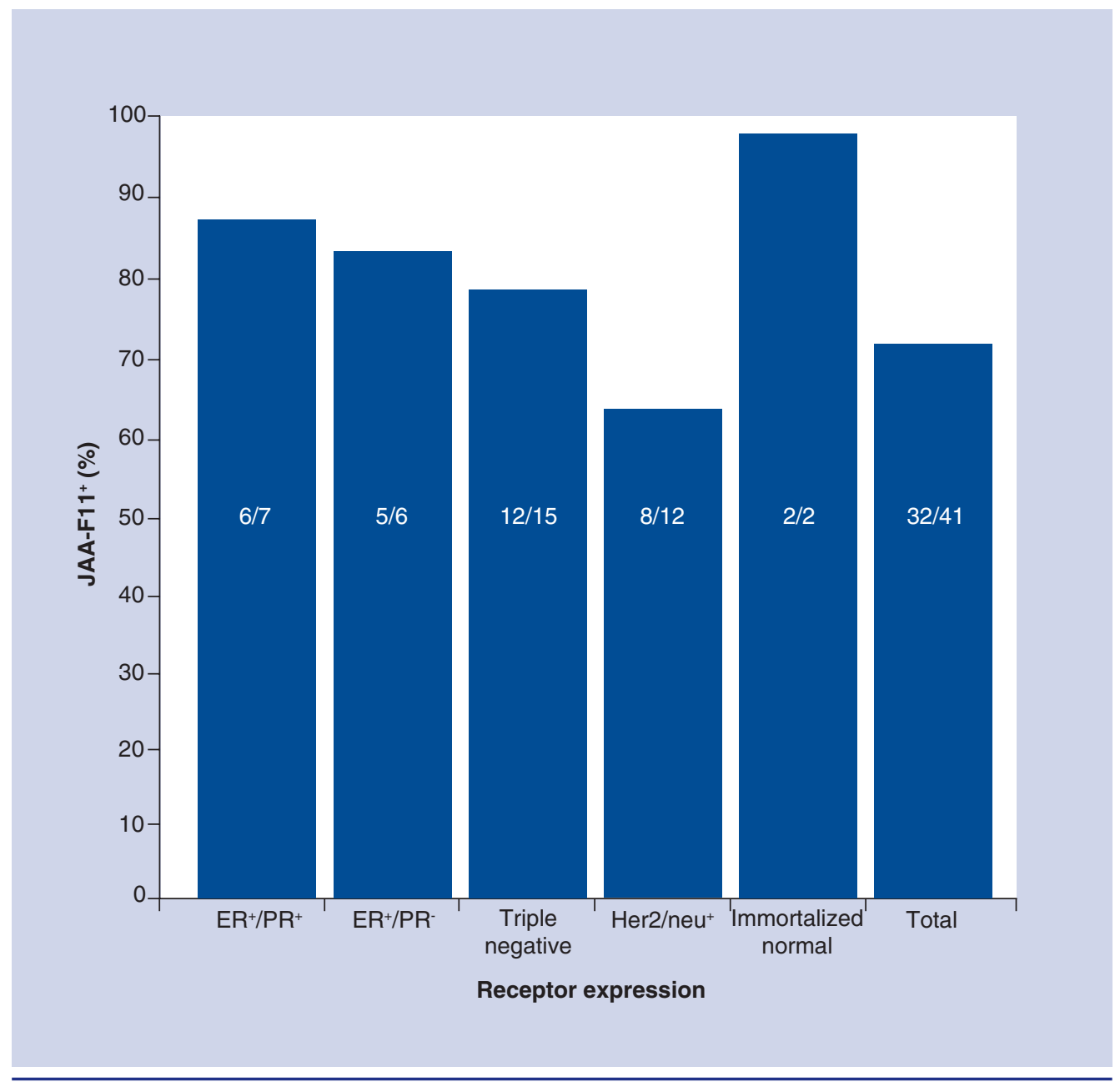

Figure 2. Percentage JAA-F11-binding human breast cancer cell lines in relation to receptor expression. Percentage TF-positive human breast cancer cell lines are shown as it relates to $\mathrm{ER}^{+} / \mathrm{PR}^{+}$, $\mathrm{ER}^{+} / \mathrm{PR}^{-}$, triple-negative, $\mathrm{HER2}{ }^{+}$and unknown receptor status. Positive cell lines are those found to have optical density values in the enzyme immunoassay significantly higher than the myeloma negative control.

ER: Estrogen receptor; PR: Progesterone receptor.

Additionally, of the HER2+ tested, 67\% (8/12) were JAA-F11-reactive TF-Ag-positive. Finally, the $184 \mathrm{~B} 5$ cells that were obtained by immortalization of normal breast cells with benzo(a)pyrene were positive [30]. HCC1954, HCC1599 and CAMA-1 were statistically higher than myeloma cells in two out of the three experiments. The remaining 25 cell lines were statistically significant in three of the three experiments. It should be noted that ZR-75-30, BT-474 and UACC812 were counted as ER+/PR', as well as HER2+.

\section{- MTT assay to assess the effect of JAA-F11 on human cancer cell proliferation}

MTT assays were performed to determine the direct effect of JAA-F11 compared to PNA on tumor cell growth in vitro. A triple-negative breast cancer cell line HCC1937 and a ER+/PR+ cell line, T47D were utilized. The graph shown in Figure $3 \mathrm{~A}$ represents a summary of the readings for all 3 days the experiments was carried out on HCC1937 (36 wells per treatment concentration). In Figure $3 \mathrm{~A}$, the triple-negative cell line, HCC1937, showed a significant dose-dependent increase in cell proliferation when treated with PNA, compared with control untreated cells, as well as a significant dose-dependent decrease in cell proliferation when treated with JAA-F11 control untreated cells. The Pearson correlation coefficient shows a statistically significant relationship ( $p<0.01$ ) of dose of either JAA-F11 or PNA to HCC1937 cellular proliferation 
RESEARCH ARTICLE Ferguson, Yadav, Morey et al.

Table 1. Breast cancer cell line receptor status for estrogen receptor, progesterone receptor,

HER2 and their Thomsen-Friedenreich antigen status ${ }^{\dagger}$.

\begin{tabular}{|c|c|c|c|c|c|}
\hline Cell line & ER & PR & HER2 & $\begin{array}{l}\text { JAA-F11-reactive } \\
\text { TF-Ag expression }\end{array}$ & Ref. \\
\hline BT20 & - & - & - & + & {$[21,25]$} \\
\hline BT549 & - & - & - & + & [21] \\
\hline DU 4475 & - & - & - & + & [21] \\
\hline HCC38 & - & - & - & + & [21] \\
\hline HCC70 & - & - & - & - & [21] \\
\hline HCC1599* & - & - & - & + & [21] \\
\hline HCC1395 & - & - & - & + & [21] \\
\hline HCC1806 & - & - & - & - & [21] \\
\hline HCC1937 & - & - & - & + & [21] \\
\hline MCF12A & - & - & - & + & {$[23,25]$} \\
\hline MCF10F & - & - & - & + & [25] \\
\hline MCF10A & - & - & - & + & {$[23,24]$} \\
\hline MDA-MB-468 & - & - & - & - & {$[21,25]$} \\
\hline MDA-MB-453 & - & - & - & + & {$[21,23,24]$} \\
\hline MDA-MB-231 & - & - & - & + & {$[21,25]$} \\
\hline MDA-MB-436 & - & - & - & + & [21] \\
\hline HCC202 & - & - & + & + & {$[22,23]$} \\
\hline HCC1419 & - & - & + & + & [22] \\
\hline HCC1569 & - & - & + & + & {$[22,23]$} \\
\hline HCC1954* & - & - & + & + & {$[22,23]$} \\
\hline HCC2218 & - & - & + & - & {$[22,24]$} \\
\hline SK-BR-3 & - & - & + & - & {$[23,25]$} \\
\hline UACC893 & $-[24,27],+[26]$ & - & + & + & {$[24,26]$} \\
\hline Au565 & - & - & + & - & {$[23,25]$} \\
\hline HCC1428 & + & + & - & + & [24] \\
\hline HCC1500 & + & + & - & + & [24] \\
\hline MCF-7 & + & + & - & + & {$[23,25,26]$} \\
\hline T47D & + & + & - & + & [23] \\
\hline BT474 $^{\ddagger}$ & $+[23,24],-[25]$ & + & + & - & - \\
\hline MDA-MB-361 ${ }^{\ddagger}$ & + & $+[24,27],-[23]$ & + & + & [23] \\
\hline $\begin{array}{l}\text { MDA-MB-175- } \\
\text { VII }\end{array}$ & + & - & - & - & {$[23,24,26]$} \\
\hline MDA-MB-415 & + & - & - & + & {$[23,26]$} \\
\hline CAMA-1* & + & - & - & + & {$[23,26]$} \\
\hline ZR-75-30 & + & - & + & + & {$[23,24,26]$} \\
\hline UACC-812 & + & - & + & + & {$[23,24]$} \\
\hline ZR-75-1 $1^{\ddagger}$ & + & $-[23,24],+[25]$ & $\begin{array}{l}-[24,26],+ \\
\text { but not over } \\
\text { expressed }[25]\end{array}$ & + & {$[23-25]$} \\
\hline MDA-kb2 $2^{\S}$ & - & - & - & - & \\
\hline \multicolumn{6}{|c|}{$\begin{array}{l}\text { The triple-negative cell lines are in the top } 16 \text { rows. All experiments were repeated three times. } \\
\text { *Statistically significantly different from myeloma cells two of the three times, all other cell lines were statistically significantly } \\
\text { different three of three times. } \\
\text { The receptor status of these lines are shown in the description of the American Type Culture Collection Triple Negative Breast } \\
\text { Cancer Panel on the cell line's American Type Culture Collection information page [20], in Neve et al. [25], in Kao et al. [26], in Subik } \\
\text { et al. [27], Finn et al. [28] and/or in Gully et al. [29]. } \\
\text { "Where conflicting data was seen for the receptor status, the status shown in two publications rather than one were used. } \\
\text { sMDA-kb2 is MDA-MD-453 transformed with an androgen-responsive luciferase reporter plasmid [30]. } \\
\text { 'MDA-MB-435 is a controversial cell line thought by some to be a melanoma, and by others to be a triple-negative breast cancer cell } \\
\text { line [21-22,24]. } \\
\text { "184B5 is a cell line obtained after exposure of normal breast cells to benzo(a)pyrene after which they became immortal, but not } \\
\text { malignant [30]. } \\
\text { +: Positive; -: Negative; ?: Status not known; ER: Estrogen receptor; PR: Progesterone receptor. }\end{array}$} \\
\hline
\end{tabular}


Table 1. Breast cancer cell line receptor status for estrogen receptor, progesterone receptor, HER2 and their Thomsen-Friedenreich antigen status ${ }^{\dagger}$ (cont.).

\begin{tabular}{|c|c|c|c|c|c|}
\hline Cell line & ER & PR & HER2 & $\begin{array}{l}\text { JAA-F11-reactive } \\
\text { TF-Ag expression }\end{array}$ & Ref. \\
\hline MDA-MB435" & - & - & - & + & {$[23,26]$} \\
\hline $\begin{array}{l}\text { 184B5 } \\
\text { immortalized } \\
\text { normal }{ }^{\#}\end{array}$ & - & $?$ & $?$ & + & {$[29,30]$} \\
\hline $\begin{array}{l}\text { Hs578Bst } \\
\text { immortalized } \\
\text { normal }\end{array}$ & - & - & $?$ & + & {$[22]$} \\
\hline \multicolumn{6}{|c|}{$\begin{array}{l}\text { The triple-negative cell lines are in the top } 16 \text { rows. All experiments were repeated three times. } \\
\text { *Statistically significantly different from myeloma cells two of the three times, all other cell lines were statistically significantly } \\
\text { different three of three times. } \\
\text { 'The receptor status of these lines are shown in the description of the American Type Culture Collection Triple Negative Breast } \\
\text { Cancer Panel on the cell line's American Type Culture Collection information page [20], in Neve et al. [25], in Kao et al. [26], in Subik } \\
\text { et al. [27], Finn et al. [28] and/or in Gully et al. [29]. } \\
\text { *Where conflicting data was seen for the receptor status, the status shown in two publications rather than one were used. } \\
\text { sMDA-kb2 is MDA-MD-453 transformed with an androgen-responsive luciferase reporter plasmid [30]. } \\
\text { 'MDA-MB-435 is a controversial cell line thought by some to be a melanoma, and by others to be a triple-negative breast cancer cell } \\
\text { line [21-22,24]. } \\
\text { "184B5 is a cell line obtained after exposure of normal breast cells to benzo(a)pyrene after which they became immortal, but not } \\
\text { malignant [30]. } \\
\text { +: Positive; -: Negative; ?: Status not known; ER: Estrogen receptor; PR: Progesterone receptor. }\end{array}$} \\
\hline
\end{tabular}

as measured by the MTT assay, a measure of mitochondrial activity. When the JAA-F11 antibody treatment was compared with PNA treatment, they were found to be significantly different from each other. In Figure $3 \mathrm{~B}$, the $\mathrm{ER}^{+} / \mathrm{PR}^{+} \mathrm{T} 47 \mathrm{D}$ breast cancer cell line exhibited an apparent increase in proliferation of cells, with increasing concentrations of PNA, which was not significantly different from the control. JAA-F11 treatment of the cells produced a dosedependent decrease in cell proliferation, which was significant at both 2 and $4 \mu \mathrm{g} / \mathrm{ml}$ concentrations. The Pearson correlation coefficient shows a statistically significant relationship ( $<<0.01$ ) of dose of JAA-F11 to T47D cellular proliferation as measured by the MTT assay. In a separate series of experiments, the TF-Ag-negative cell line, the myeloma, X63Ag8.653 was treated with JAA-F11 and no significant changes in growth rate occurred. This was repeated on three different days and no significant effect seen in any experiment.

\section{- Internalization of JAA-F11}

The results of the internalization experiments are shown in Figure 4. For each cell line, the absorbance result of the EIA was significantly higher for cells held at $4^{\circ} \mathrm{C}$ than for cells held at $37^{\circ} \mathrm{C}$, indicating that internalization had occurred. The percentage of antibody internalized was characterized by percentage decrease in the binding of the antimouse IgG alkaline phosphatase conjugate and subsequent decrease in substrate conversion for cells incubated at $37^{\circ} \mathrm{C}$. One representative experiment is shown for each of the three cell lines. This experiment was repeated on at least three different days for each cell line and was carried out in triplicate each day. The average internalization at $1 \mathrm{~h}$ for 4T1 cells for experiments performed on three different days was $82 \pm 3 \%$, for CAMA-1 it was $77 \pm 2 \%$, and for BT549 it was $87 \pm 1 \%$.

\section{- Radiolabeling of JAA-F11 via the Bolton-Hunter method}

In previous experiments, JAA-F11 was found to be unstable to iodogen labeling [6]. This is consistent with the crystallography and computational carbohydrate threading data, which show seven tyrosines (the labeling target of the iodogen method) to be in the binding site complementary determining regions [19]. Iodine labeling via the iodogen method sterically inhibited antigen binding. The Bolton-Hunter method of labeling lysines was therefore utilized. BoltonHunter yield is the activity obtained after attaching JAA-F11 to the Bolton-Hunter reagent. Radiolabeling yield is the percentage of activity obtained (peak activity obtained from the Sephadex G25 column; GE Healthcare Bio-Sciences, PA, USA) at the end of the experiment, compared with the activity before adding JAA-F11 antibody in the reaction mixture. The Bolton-Hunter yield of $2.65 \%$ seen in the first experiment was improved to $13.16 \%$ after fresh reagents were prepared. These yields were still 


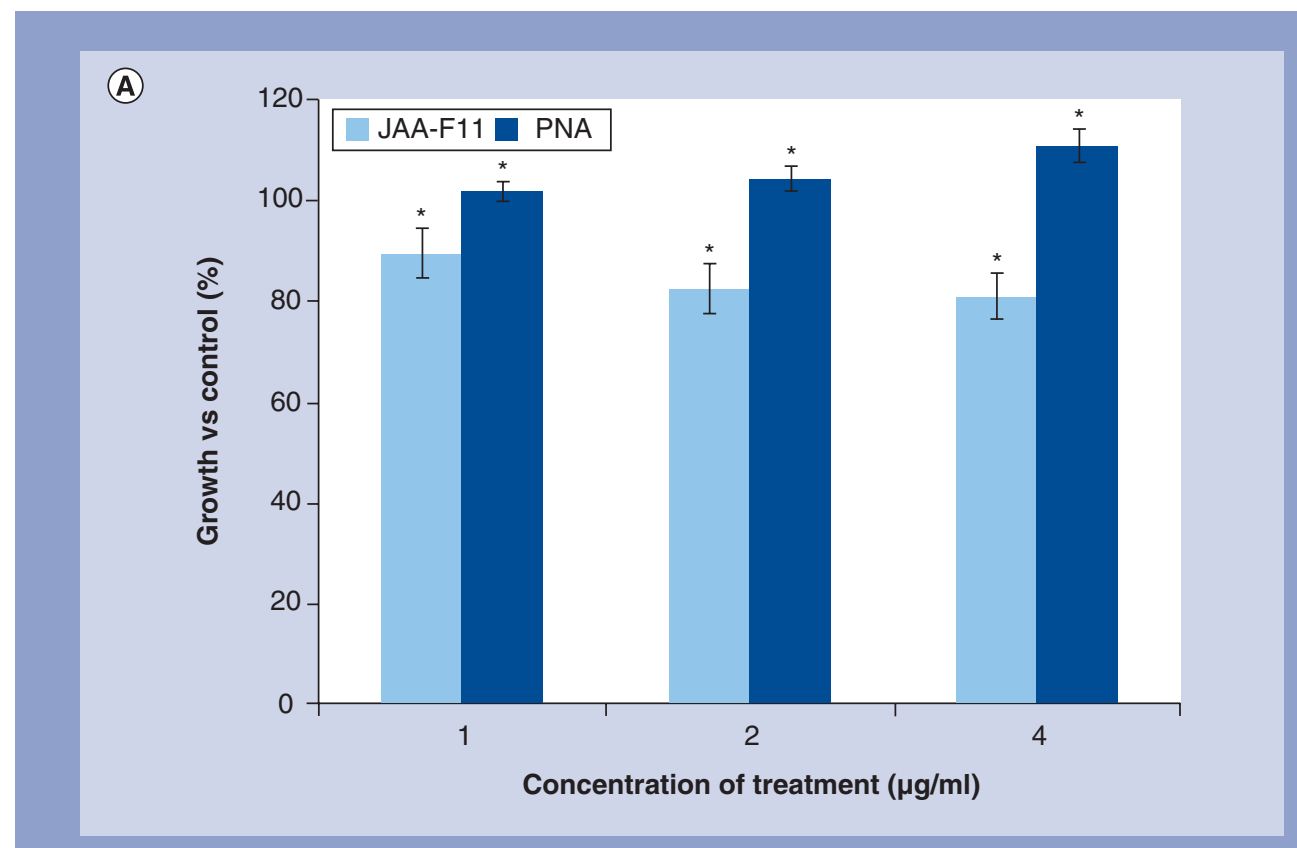

(B)

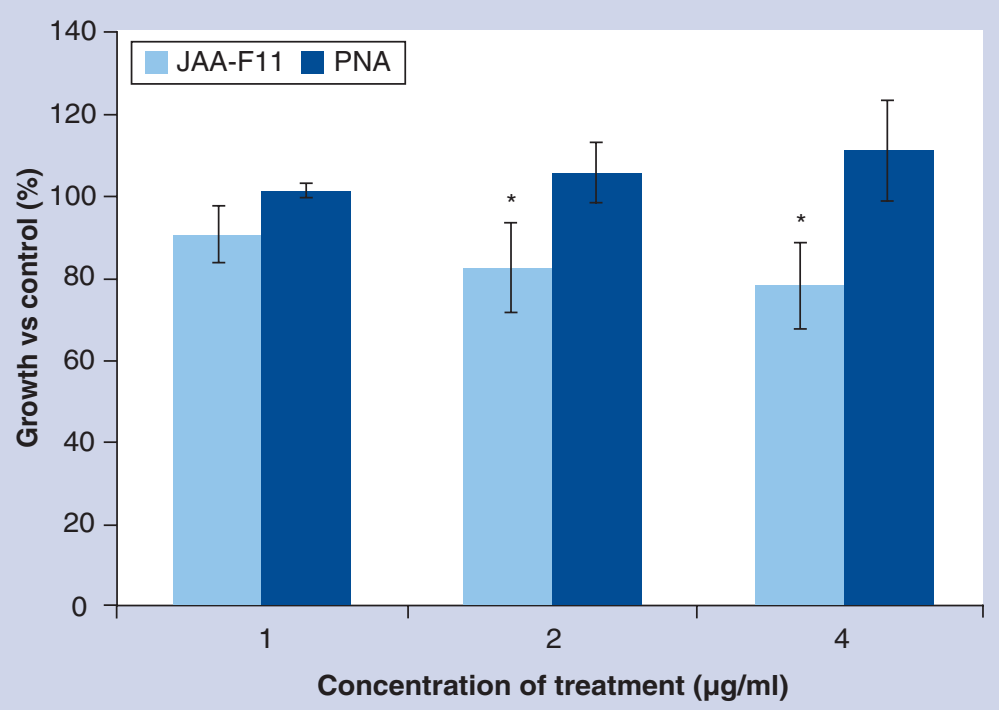

Figure 3. Effect of in vitro treatment with JAA-F11 and peanut agglutinin (4, 2 and $1 \mu \mathrm{g} / \mathrm{ml})$.

(A) Effect on cell proliferation of HCC1937 breast cancer cell line. For each cell type, the MTT value of the treated cells were divided by the MTT value of the untreated cells of the same type. Thus the percentage growth versus the control, or the controls themselves, would have been $100 \%$. Results show a statistically significant dose-dependent decrease in cell proliferation when cells were treated with JAA-F11 at all concentrations when compared with controls. Additionally, there was a statistically significant dose-dependent increase in cell proliferation when treated with peanut agglutinin at 4 and $2 \mu \mathrm{g} / \mathrm{ml}$ when compared with controls. (B) Effect on the cell proliferation of T47D breast cancer cell line. There was an apparent dose-dependent increase in proliferation of cells with increasing concentrations of peanut agglutinin. This increase and trend did not reach significant difference from control. JAA-F11 treatment of the cells produced a dose-dependent decrease in cell proliferation, which was significant at both 2 and $4 \mu \mathrm{g} / \mathrm{ml}$. The asterisk indicate that the value for the treatment is statistically different from the control untreated cells $(p<0.05)$. 
quite low. In addition, the yields of the labeled antibody from the Sephadex G25 column were quite a low: $6.39 \%$ in the first of these experiments, which was increased to $22.37 \%$ in the second experiment, indicating the nonspecific loss of antibody to the column. Although these yields were low, the purpose of these experiments was to determine if the human tumors could be visualized in SCID and nude mice, and these experiments were successful.

\section{- PET imaging of human triple-negative} breast cancer cell lines in SCID or nude mice The triple-negative human breast cancer cell line, MDA-MB-435 mouse was localized using ${ }^{124}$ I-JAA-F11 in female SCID mice as shown in Figure 5A. To decrease non-TF-Ag-specific uptake by $\mathrm{Fc}_{\mathrm{C}}$ receptors, cold antibody (intraperitoneally, $46 \mathrm{mg} /$ mouse) was given to mice 1 day prior to injecting the ${ }^{124} \mathrm{I}-\mathrm{JAA}-\mathrm{F} 11$ in the first experiment. The origins of MDA-MB-435 have become controversial, with some indications that it is a melanoma cell line [22], and some indications that it is, as originally classified, a triple-negative breast cancer cell line $[23,25]$. This imaging was repeated with MDA-MB-231 triple-negative cells. In Figure 5B, MDA-MB-231 triple-negative cells localized using ${ }^{124} \mathrm{I}-\mathrm{JAA}-\mathrm{F} 11$ in SCID mice. In this experiment, PET images with a very clear location of the tumor were obtained for up to 24 days after injection of ${ }^{124}$ I-JAA-F11. At some later time points, a transmission scan was performed to get the outline of the animal. The emission and transmission scans were fused to get the final images from day 15 onwards. The final weight of the MDA-MB-231 tumor at $576 \mathrm{~h}$ was $0.088 \mathrm{~g}$, indicating a sensitivity of less than $0.09 \mathrm{~g}$ throughout all the images.

Two nude mice with both TF-Ag-positive (triple-negative DU 4475 ATCC HTB-123) and a TF-Ag-negative (MDA MB 468 ATCC HTB132) tumors were injected with radiolabeled JAA-F11. MicroPET images to $192 \mathrm{~h}$ showed localization of the radiolabeled JAA-F11 antibody to TF-Ag-positive tumor in both mice. The nude mice were sacrificed at approximately $196 \mathrm{~h}$ due to the tumor size of the TF-Ag-positive tumor. The negative tumor grew much more slowly than the TF-Ag-positive tumor so no conclusion can be made concerning the TF-Agnegative tumor $(1.2 \mathrm{~g}$ for the positive tumor and $0.04 \mathrm{~g}$ for the negative tumor in one mouse, and $3.02 \mathrm{~g}$ for the positive tumor and $0.06 \mathrm{~g}$ for the negative tumor in the second mouse).
The transmission scan could not be performed due to instrumentation failure, so only one time point is shown $(72 \mathrm{~h})$, since without the transmission image the scan is less useful at longer time points (Figure 5C). Despite the limitations of this experiment, tumor localization of JAA-F11 to DU 4475 was apparent.

\section{Discussion}

TF-Ag expression on the surface of breast cancer cells using the EIA technique demonstrated that $78 \%$ of all cell lines tested were positive for JAA-F11 binding to TF-Ag and that $80 \%$ of the triple-negative cell lines were positive for JAA-F11 binding. This is promising for JAA-F11

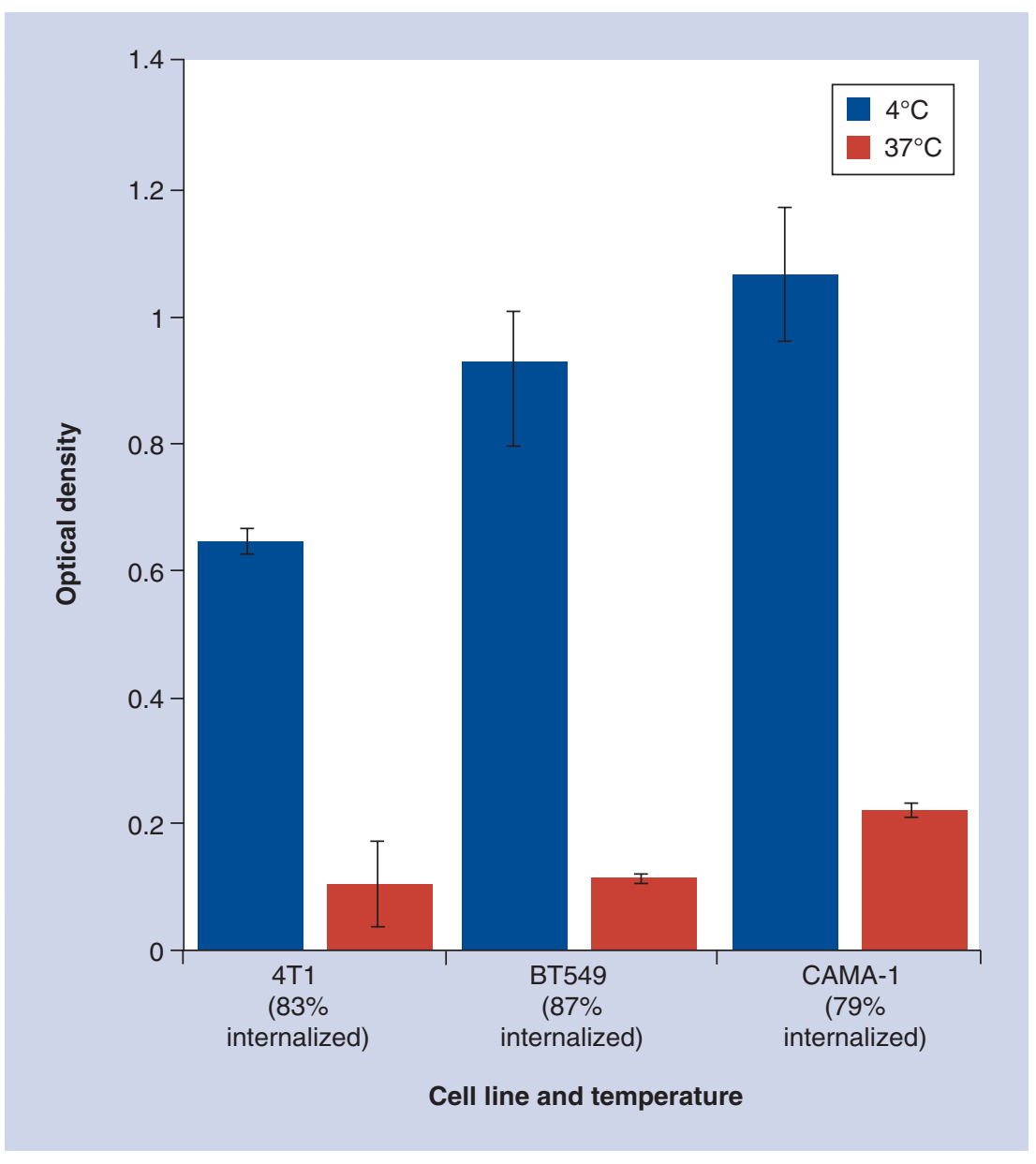

Figure 4. The percentage internalization of JAA-F11 at $1 \mathrm{~h}$ at $37^{\circ} \mathrm{C}$ compared with $1 \mathrm{~h}$ at $4^{\circ} \mathrm{C}$ for three cell lines. An enzyme immunoassay was performed on confluent cells in two different six-well plates, one in which the JAA-F11 was incubated at $4^{\circ} \mathrm{C}$ versus the second plate, which was held at $37^{\circ} \mathrm{C}$. The wells were performed in triplicate and control wells of cells incubated without the primary antibody were used as media controls for the enzyme activity in this enzyme immunoassay. This representative experiment shows $83 \%$ internalization in 4T1 cells, $87 \%$ internalization in BT549 cells and 79\% internalization in the CAMA-1 cells. 


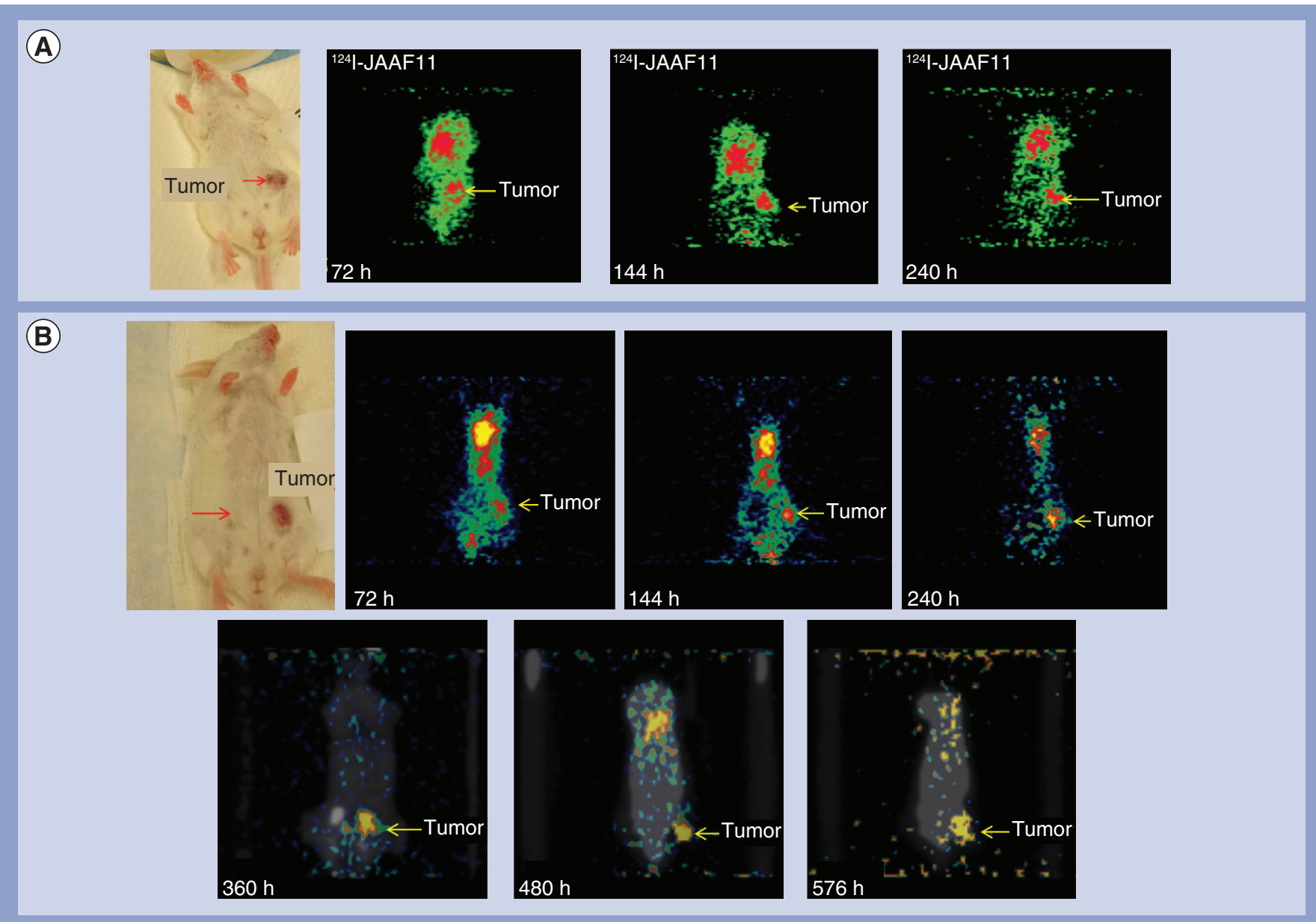

(C)

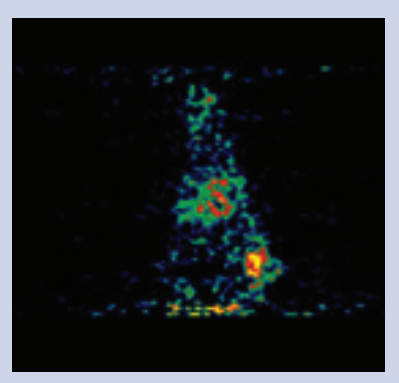

Figure 5. In vivo human tumor localization of JAA-F11 in mice. (A) MicroPET immunolocalization of ${ }^{124}$ I-JAA-F11 in severe combined immunodeficiency (SCID) mouse with the triple-negative human breast tumor (MDA-MB-435) after cold antibody treatment. (B) MicroPET immunolocalization of ${ }^{124} \mathrm{I}-\mathrm{JAA}-\mathrm{F} 11$ in SCID mouse with the triple-negative human breast tumor, MDA-MB-231 (without cold antibody treatment). (C) MicroPET image of nude mouse with-triple negative DU 4475 ATCC HTB-123 tumor. Mice received autoclaved $0.2 \mathrm{~g} / \mathrm{I} \mathrm{KI}$ water to block thyroid uptake $24-48 \mathrm{~h}$ prior to receiving ${ }^{124} \mathrm{I}-\mathrm{JAA}-\mathrm{F} 11$. Mice received a tail vein infusion of $10 \mu \mathrm{g}$ JAA-F11 labeled with $10-120 \mu \mathrm{Ci}{ }^{124} \mathrm{I}$ in $0.1 \mathrm{ml}$ phosphate-buffered solution. In (A), the MDA-MB-435 tumor SCID mouse was given an intraperitoneal


tumor-bearing SCID mouse and a DU 4475 ATCC HTB-123-bearing nude mouse were injected with radiolabeled antibody without pretreatment with cold antibody. Mice were anethesized and imaged by microPET at the hours shown after injection of ${ }^{124}$ I-JAA-F11 and were sacrificed on the last day of the study. The animal was scanned for $30 \mathrm{~min}$ for ${ }^{124}$ in the prone position in the gantry of the microPET scanner. The hot spot above the tumor in early time points is the blood pool circulating antibody that is in the heart. The hot spot in (B) at 72 and $144 \mathrm{~h}$ may be urine-associated free ${ }^{124} \mathrm{I}$ in the bladder.

For color image, please see www.futuremedicine.com/doi/full/10.2217/fon.13.209 
to be further studied as a possible therapeutic agent for treating triple-negative breast cancer, as there are no targeted therapies available for those types of cancer.

In support of the EIA data for detecting TF-Ag-positive cells, multiple other studies have shown that approximately $80 \%$ of human breast carcinomas are positive for TF-Ag [17,31-36], usually by immunohistochemistry. Not all antiTF-Ag antibodies are useful in immunohistochemistry, and JAA-F11 currently fits in this group, although efforts are being made in our laboratory to develop appropriate fixation methods for immunohistochemistry with JAA-F11. While not binding reproducibly in immunohistochemistry in protocols that we have currently attempted, it shows excellent specificity, binding only the tumor-associated TF-Ag $\alpha$-linked and not the normal tissue-associated TF-Ag $\beta$-linked. In addition, it shows excellent sensitivity, with successful tumor imaging shown when the tumor was $\leq 0.09 \mathrm{~g}$ (Figure 5B). In previous work, JAA-F11 was shown to function as an antimetastatic in a number of assays $[16,17,33,34]$, including assays with human tumor cells, extending the antimetastatic function to the following human tumor cells: MDA-MB-435 (breast cancer or melanoma), Du-145 prostate cancer cells and HT29 LMM colon cancer cells $[17,33,34]$. In addition, in previous studies from our laboratory [16], utilizing JAA-F11 at 4,2 and $1 \mu \mathrm{g} / \mathrm{ml}$ in MTT assays produced a significant decrease in cell proliferation in the mouse breast cancer cell line 4T1 when compared with a control. The experiments herein confirm this decrease and add information concerning human tumor cell growth inhibition by JAA-F11. Both human cell lines showed a decrease in cell proliferation at 4 and $2 \mu \mathrm{g} / \mathrm{ml}$. The triple-negative cell line HCC1937 showed significant decreases in in vitro proliferation at all concentrations when comparing JAA-F11 antibody with control (cells growth without treatment) or JAA-F11 antibody with PNA lectin. The $\mathrm{ER}^{+}, \mathrm{PR}^{+}$and HER2- cell line T47D also showed a decrease in proliferation at all concentrations of JAA-F11, which reached significance at 2 and $4 \mu \mathrm{g} / \mathrm{ml}$. PNA (Arachishypogaea) is a lectin that has long been used for the detection of TF-Ag on the surface of carcinoma cells $[35,36]$. PNA has been shown to increase proliferation of TF-Ag-bearing tumor cells [36]. Owing to this proliferation-stimulating characteristic, it was chosen as a treatment to compare the effect of JAA-F11 on tumor cells.
In the experiment, PNA displayed the expected stimulating effect on human tumor cells. This proliferation reached significance at two concentrations (2 and $4 \mu \mathrm{g} / \mathrm{ml}$ ) when incubated with HCC1937, while JAA-F11-treated cells showed a significant decrease.

JAA-F11 internalization showed remarkable consistency in three cell lines tested, with incubation for $1 \mathrm{~h}$ at $37^{\circ} \mathrm{C}$ resulting in approximately $80 \%$ of the antibody internalized at $37^{\circ} \mathrm{C}$ compared with the control held at $4^{\circ} \mathrm{C}$. This internalization may facilitate use as an antibody-drug conjugate.

The in vivo experiments shown here are not attempts to perfect in vivo localization with JAA-F11, they were performed to confirm the in vitro JAA-F11 binding results shown in our EIA with in vivo binding. The in vivo binding did confirm our in vitro results with human cell lines. Other microPET images and more detailed experiments with JAA-F11 in microPET can be seen in our previous paper [6]. Importantly, JAA-F11 did not show kidney binding seen by other mAbs, which have been used to target TF-Ag. Tru-Scint ${ }^{\mathrm{TM}}$ (Biomira, Inc., Alberta, Canada), an anti-TF-Ag antibody, which reached Phase III clinical trials for tumor imaging showed an $83.5 \%$ overall sensitivity and a $97.7 \%$ positive predictive value, even though some of the antibody was lost to binding to the patient's kidney cells . The lack of kidney binding of JAA-F11 in the mouse model, and the improved chemical specificity of JAA-F11 indicates that the off-target binding that limited the otherwise successful Tru-Scint may be bypassed.

\section{Conclusion \& future perspective}

Given the success of JAA-F11 [16] in: human and mouse tumor cell growth inhibition in vitro; metastasis inhibition in several models of metastasis with human breast, colon and prostate cancer cells; selectively binding to both human and mouse tumor cells in vivo; presence on approximately $80 \%$ of breast cancer cell lines; and internalization within $1 \mathrm{~h}$ in tumor cells, we are pursuing humanization of JAA-F11 with the hopes that humanized JAA-F11 can be used therapeutically to increase survival for patients with breast cancers. This should be especially important for triple-negative breast cancers for which there are no targeted therapies. We expect the humanized JAA-F11 IgG $\mathrm{Ig}_{1}$ may be able to function through direct killing because of the enhanced biologic function of the $\operatorname{IgG}_{1}$ 
molecule. We also anticipate that, in a manner similar to the mouse antibody, the humanized antibody may function by blocking metastasis of these tumors. In addition, since JAA-F11 has been shown to internalize rapidly, it may be of use as part of an antibody-drug conjugate in cancer therapy.

Financial \& competing interests disclosure $K$ Rittenhouse-Olson has patented JAA-F11 and has recently incorporated a company with the name 'For-Robin, Inc.' with the mission of development of this antibody for buman cancer therapy. She is currently sole owner of this company. More information about this company can be seen at http://for-robin.com/. For-Robin, Inc. recently received NIH STTR funding. This interest did not affect the interpretation of the data or the design of the experiments in any way. The authors acknowledge and give thanks for the grant support of CDMRP W81XWH-04-1-0342, Oncologic Foundation of Buffalo, UB STOR Product Development Fund, NIAID R15 AI 49210-01, the Oishei Foundation, The Bruce Holm Catalyst Fund and the Mark Diamond Research Foundation of the State University of New York at Buffalo grant number SP-11-05. The authors would like to acknowledge support of the following grants: the Mark Diamond Research Foundation and the Organization of American States (KFerguson), the Oishei Foundation, The National Cancer Institute grant NIH 1 R41 CA176951-01 and the Bruce Holm Memorial Catalyst Fund (K Rittenhouse-Olson) and the NSF grant 1204209 ( $G$ Hrysenko). The authors have no other relevant affiliations or financial involvement with any organization or entity with a financial interest in or financial conflict with the subject matter or materials discussed in the manuscript apart from those disclosed.

No writing assistance was utilized in the production of this manuscript.

\section{Ethical conduct of research}

The authors state that they have obtained appropriate insti-tutional review board approval or have followed the princi-ples outlined in the Declaration of Helsinki for all human or animal experimental investigations. In addition, for investi-gations involving human subjects, informed consent has been obtained from the participants involved.

\section{EXECUTIVE SUMMARY}

To continue clinical translational studies of the monoclonal antibody (mAb) JAA-F11:

- Reactivity against the American Type Culture Collection panel of human breast cancer cell line was tested in vitro and of the 41 human cell lines tested:

- 32 were JAA-F11-reactive Thomsen-Friedenreich antigen (TF-Ag)-positive (78\%);

- The reactivity was independent of estrogen/progesterone receptors or HER2 status.

- In vivo testing using ${ }^{124}$-labeled antibody confirmed JAA-F11 binding to human triple-negative breast cancer cell lines in vivo.

- JAA-F11 was also shown to inhibit growth of the human tumor cells in vitro.

- JAA-F11 was shown to internalize in cancer cells ( $80 \%$ within $1 \mathrm{~h})$.

These points show the potential of a humanized JAA-F11 as an immunotherapeutic and as an antibody-drug conjugate.

\section{References}

Papers of special note have been highlighted as:

- of interest

- of considerable interest

1 Siegel R, Ward E, Brawley O, Jemal A. Cancer statistics, 2011. CA Cancer J. Clin. 61(4), 212-236 (2011).

2 Damasceno M. Bevacizumab for the first-line treatment of human epidermal growth factor receptor 2-negative advanced breast cancer. Curr. Opin. Oncol. 23, S3-S9 (2011).

3 Naomoto Y, Sadamori H, Matsukawa H et al. Multiple liver metastases of breast cancer: report of a case successfully treated with hormone-cytokine-chemotherapy. Jpn J. Clin. Oncol. 29(8), 390-394 (1999).

4 Glinsky V, Huflejt ME, Glinsky GV, Deutscher SL, Quinn TP. Effects of ThomsenFriedenreich antigen-specific peptide P-30 on betagalactoside-mediated homotypic aggregation and adhesion to the endothelium of MDA-MB-435 human breast carcinoma cells. Cancer Res. 60, 2584-2588 (2000).

5 Jothy S, Munro SB, Leduy L, McClure D, Blaschuk OW. Adhesion or anti-adhesion in cancer: what matters more? Cancer Metast. Rev. 14(4), 363-376 (1995).

6 Chaturvedi R, Heimburg J, Yan J et al. Tumor immunolocalization using ${ }^{124} \mathrm{I}$-iodine- labeled JAA-F11 antibody to ThomsenFriedenreich alpha-linked antigen. Appl. Radiat. Isotopes 66(3), 278-287 (2008).

- Highlights the specificity of JAA-F11 to the Thomsen-Friedenreich antigen (TF-Ag) and the fact that it remains at the site of the tumor for a fairly long period.

7 Steinborn DW, Büschenfelde A, Meyer Zum $\mathrm{KH}$. The role of the Thomsen-Friedenreich antigen as a tumor-associated molecule. Environ. Health Perspect. 88, 255-257 (1990).

8 Springer GF, Desai PR, Scanlon EF. Blood group MN precursors as human breast carcinoma-associated antigens and 'naturally' 
occurring human cytotoxins against them. Cancer 37(1), 169-176 (1976).

9 Springer G, Desai PR, Murthy MS, Scanlon EF. Human carcinoma-associated precursor antigens of the MN blood group system. J. Surg. Oncol. 11, 95-106 (1979).

10 Glinsky VV, Glinsky GV, Rittenhouse-Olson $\mathrm{K}$ et al. The role of Thomsen-Friedenreich antigen in adhesion of human breast and prostate cancer cells to the endothelium. Cancer Res. 61(12), 4851-4857 (2001).

11 Senapati S, Chaturvedi P, Chaney WG et al. Novel interaction of MUC4 and galectin: potential pathobiological implications for metastasis in lethal pancreatic cancer. Clin. Cancer Res. 17(2), 267-274 (2011).

12 Springer G. T and Tn, general carcinoma autoantigens. Science 224, 1198-1206 (1984).

13 Rittenhouse-Olson K. JAA-F11. Expert Opin. Biol. Ther. 7(7), 923-928 (2007).

14 Rittenhouse-Diakun K, Xia Z, Pickhardt D, Morey S, Baek MG, Rene R. Development and characterization of monoclonal antibody to T-Antigen: (Galßl-3GalNAc- $\alpha-O)$. Hybridoma 17(2), 165-173 (1998).

15 Mcquarrie S, Maclean G, Boniface G, Goldberg K, McEwan A.

Radioimmunoscintigraphy in patients with breast adenocarcinoma using technetium-99m labelled monoclonal antibody 170H.82: report of a Phase II study. Eur. J. Nucl. Med. Mol. Imaging 24, 381-389 (1997).

16 Heimburg J, Yan J, Morey S et al. Inhibition of spontaneous breast cancer metastasis by anti-Thomsen-Friedenreich antigen monoclonal antibody JAA-F11. Neoplasia 8(11), 939-948 (2006).

-. Highlights the fact that with JAA-F11, there were fewer metastases and mice lived longer than those bearing tumors, but not treated with JAA-F11.

17 Gassman P, Kang M, Mees S, Haier J. In vivo tumor cell adhesion in the pulmonary microvasculature is exclusively mediated by tumor cell-endothelial cell interaction. BMC Cancer 10, 177 (2010).
- Highlights the importance of TF-Ag in metastasis and utilizes JAA-F11 to block metastasis.

18 Oakman C, Viale G, Di Leo A. Management of triple negative breast cancer. Breast 19(5), 312-321 (2010).

19 Tessier M, Grant O, Heimburg-Molinaro J, Jadey S, Gulick A. Computational screening of the human TF-glycome provides a structural definition for the specificity of anti-tumor antibody JAA-F11. PLoS ONE 8(1), e54874 (2012).

20 American Type Culture Collection. The essentials of life research: ATCC TripleNegative Breast Cancer Panels. www.atcc.org/ /media/ Attachments/C/9/5/6/28969.ashx

21 Ross D, Scherf U, Eisen M, Perou C, Rees C. Systematic variation in gene expression patterns in human cancer cell lines. Nat. Genet. 24, 227-235 (2000).

22 Chambers A. MDA-MB-435 and M14 cell lines: Identical but not M14 melanoma? Cancer Res. 69, 5292-5293 (2009).

23 Hollestelle A, Schutte M. Comment Re: MDA-MB-435 and M14 cell lines: Identical but not M14 melanoma? Cancer Res. 69, 7893 (2009).

24 Wilson V, Bobseine K, Lambright C, Gray L. A novel cell line, MDA-kb2, that stably expresses an androgen- and glucocorticoidresponsive reporter for the detection of hormone receptor agonists and antagonists. Toxicol. Sci. 66, 69-81 (2002).

25 Neve R, Chin K, Fridlyand J, Yeh J, Baehner F. A collection of breast cancer cell lines for the study of functionally distinct cancer subtypes. Cancer Cell 10, 515-527 (2006).

26 Kao J, Salari M, Bocanegra Y, Choi L, Girard J. Molecular profiling of breast cancer cell lines defines relevant tumor models and provides a resource for cancer gene discovery. PLoS ONE 4, 0006146 (2009).

27 Subik K, Lee J, Baxter L, Strzepek T, Costello D. The expression patterns of ER, PR, HER2, CK5/6, EGFR, Ki-67 and AR by immunohistochemical analysis in breast cancer cell lines. Breast Cancer 4, 35-41 (2010).

28 Finn R, Dering J, Dering J, Conklin O, Conklin D. PD 0332991, a selective cyclin D kinase 4/6 inhibitor, preferentially inhibits proliferation of luminal estrogen receptorpositive human breast cancer cell lines in vitro. Breast Cancer Res. 11, R77 (2009).

29 Gully C, Zhang F, Chen J, Yeung J, Velazquez-Torres G. Antineoplastic effects of an Aurora B kinase inhibitor in breast cancer. Mol. Cancer 9, 42 (2010).

30 Stampfer M, Bartley J. Induction of transformation and continuous cell lines from normal human mammary epithelial cells after exposure to benzo[a]pyrene. Proc. Natl Acad. Sci. USA 82, 2394-2398 (1985).

31 Almogren A, Abdullah J, Gharpure K, Ferguson K, Glinsky V, Rittenhouse-Olson K. Anti-Thomsen Friedenreich-Ag (Anti-TF$\mathrm{Ag})$ potential for cancer therapy. Front. Biosci. 4, 840-863 (2012).

- Summarizes the importance of TF-Ag as a target in tumor immunotherapy.

32 Springer GF. Immunoreactive $\mathrm{T}$ and $\mathrm{Tn}$ epitopes in cancer diagnosis, prognosis, and immunotherapy. J. Mol. Med. 75(8), 594-602 (1997).

33 Glinskii O, Huxley V, Glinsky G, Pienta K, Raz A. Mechanical entrapment is insufficient and intercellular adhesion is essential for metastatic cell arrest in distant organs. Neoplasia 7, 522-527 (2005).

34 Glinsky VV, Glinsky GV, Rittenhouse-Olson $\mathrm{K}$ et al. The role of Thomsen-Friedenreich antigen in adhesion of human breast and prostate cancer cells to the endothelium. Cancer Res. 61(12), 4851-4857 (2001).

35 Limas C, Lange P. T-Antigen in normal and neoplastic urothelium. Cancer 58(6), 1236-1245 (1986).

36 Irazoqui F, Janson, B, Lopez PHH, Nores GA. Correlative fine specificity of several ThomsenFriedenreich disaccharide-binding proteins with an effect on tumor cell proliferation. J. Biochem. 130(1), 33-37 (2001). 